\title{
FAKTOR-FAKTOR YANG BERHUBUNGAN DENGAN TINDAKAN MEMBUANG SAMPAH DI LINGKUNGAN IV KELURAHAN HELVETIA KECAMATAN MEDAN HELVETIA TAHUN 2017
}

\section{Factors Which Were Correlated With the Behavior of Action Throwing Garbage at Lingkungan IV, Kelurahan Helvetia, Medan Helvetia, in 2017}

\author{
Napis Alfikri $^{1}$, Wisnu Hidayat ${ }^{2}$, Vierto Irennius Girsang ${ }^{2}$ \\ ${ }^{1}$ Program Studi Pasca Sarjana Kesehatan Masyarakat Universitas Sari Mutiara Indonesia \\ Email : napisalfikri1@gmail.com \\ ${ }^{2}$ Dosen Program Studi Pasca Sarjana Kesehatan Masyarakat \\ Universitas Sari Mutiara Indonesia \\ Email: wisnu@yahoo.com
}

\begin{abstract}
Abstrak
Sampah merupakan konsekuensi dari adanya aktivitas manusia, yang pastinya menghasilkan buangan atau sampah. Kota Medan terdapat 2000 ton sampah diproduksi per harinya, sebagian besar yang banyak menyumbang sampah tersebut merupakan hasil dari sampah rumah tangga yaitu kegiatan ibu rumah tangga yang mencapai 1500 ke 1600 ton per hari yang disebabkan oleh bebrapa faktor yaitu predisposisi, pemungkin dan penguat. Penelitian ini bertujuan untuk mengetahui faktor-faktor yang berhubungan dengan tindakan membuang sampah di Lingkungan IV Kelurahan Helvetia Kecamatan Medan Helvetia Tahun 2017. Populasi sebanyak 178 orang, sedangkan sampel sebanyak 123 orang. Jenis penelitian menggunakan observasional analitik dengan menggunakan rancangan Cross Sectional dengan analisis data dilakukan secara univariat, bivariat dan multivariat. Hasil penelitian terdapat hubungan pengetahuan ( $p$ value $=<0,001)$, sikap ( $p$ value $=0,004)$, pendidikan $(p$ value $=<0,001)$, ketersediaan sarana $(p$ value $=<0,001)$, sosialisasi petugas kesehatan ( $p$ value $=<0,001)$, pengetahuan tentang perda no 6 tahun 2015 ( $p$ value $=<0,040)$. Variabel yang paling dominan berhubungan dengan membuag sampah adalah pengetahuan yaitu 8,6 kali lebih besar membuang sampah secara baik dibandingkan mereka yang memiliki pengetahuan yang tidak baik. Disarankan kepada pihak pemerintah agar melakukan evaluasi secara berkala serta melakukan promosi kesehatan lingkungan dan mengikutsertakan tokoh masyarakat dalam berperilaku membuang sampah.
\end{abstract}

Kata kunci : Predisposisi, Pemungkin, Penguat, Tindakan Membuang Sampah

\begin{abstract}
Garbage is the consequence human activity in the form of disposal or waste. There are 2000 tons of garbage per day in Medan, and most of the garbage which comes from people's homes and is produced by housewives reaches to 1,500 to 1,600 tons per day. which is caused by several factors that are predisposition, enabler and amplifier. The objective of the research was to find out some factors which were correlated with the behavior of action throwing garbage at Lingkungan IV, Kelurahan Helvetia, Medan Helvetia, in 2017. The population was 178 people, and 123 of them were used as the samples. The research used observational analytic method with cross sectional design. The data were analyzed by using univariate anaslysis, bivariate analysis, and multivariate analysis. The result of the research showed that there was the correlation of knowledge ( $\mathrm{p}$-value $=$ $<0.001)$, attitude ( $\mathrm{p}$-value $=0.004)$, education ( $\mathrm{p}$-value $=<0.001)$, availability of facility ( $\mathrm{p}$-value $=$ $<0.001$ ), socialization of health care providers ( $\mathrm{p}$-value $=<0.001$ ), and knowledge about perda no 6 year 2015 (p-value $=<0.004$ ) of throwing garbage. The variable which had the most dominant correlation with of throwing garbage was knowledge which 8.6 times of the possibility to be a good behavior in throwing garbage compared with those who had bad knowledge. It is recommended that the Government do regular evaluation and promote environmental health by making public figures participate in good behavior of throwing garbage.
\end{abstract}

Keywords: Predisposition, Enabling, Enforcing, Action Throwing Garbage 


\section{PENDAHULUAN}

Dalam rangka menyukseskan visi misi di atas, salah satu masalah yang menonjol adalah kesehatan masyarakat yang tak lepas dari lingkungan yangkondusif diharapkan pada masa depan agar terwujudnya keadaan sehat yaitu lingkungan yang bebas dari polusi dan sanitasi lingkungan yang memadai. Masalah lingkungan merupakan suatu hal yang kompleks sehingga mengatasinya diperlukan upaya perbaikan sanitasi lingkungan, salah satunya yaitu penanganan sampah secara saniter. Sebagaimana biasanya penduduk yang padat banyak digunakan orang untuk membuang sampah yang bersifat bercampur dengan sampah-sampah berbahaya, selain itu saat ini tanah juga di gunakan untuk membuang sampah berbahaya yang secara cair maupun padat (Slamet,2009).

Data di Kementerian Lingkungan Hidup (KLH) Tahun 2010 menyebutkan, volume rata-rata sampah di Indonesia mencapai 300 ribu ton per hari. Daerah perkotaan menyumbang sampah paling banyak. Di Indonesia, jumlah sampah padat yang diproduksi secara nasional mencapai 151.921 ton per hari. Hal itu berarti, setiap penduduk Indonesia ratarata membuang sampah padat sebesar $0,85 \mathrm{~kg}$ setiap hari. Data Bank Dunia juga menyebutkan, dari total sampah yang dihasilkan secara nasional, hanya $80 \%$ yang berhasil dikumpulkan. Sisa terbuang mencemari lingkungan. Volume sampah di Indonesia sekitar 1 juta meter kubik setiap hari, namun baru $42 \%$ di antaranya yang terangkut dan diolah dengan baik. Jadi, sampah yang tidak diangkut setiap harinya sekitar 348.000 meter titik atau sekitar 300.000 ton(Partneship,2011).

Sampah selalu timbul menjadi persoalan rumit dalam masyarakat yang kurang memiliki kepekaan terhadap lingkungan.Ketidakdisiplinan mengenai kebersihan dapat menciptakan suasana semrawut akibat timbunan sampah. Begitu banyak kondisi tidak menyenangkan akan muncul. Bau tidak sedap, lalat berterbangan, dan gangguan berbagai penyakit siap menghadang di depan mata. Tidak cuma itu, peluang pencemaran lingkungan disertai penurunan kualitas estetika pun akan menjadi santapan sehari-hari bagi masyarakat (Aminah, 2016).

Keberadaan sampah di kehidupan sehari-hari tak lepas dari tangan manusia yang membuang sampah sembarangan, mereka menganggap barang yang telah dipakai tidak memiliki kegunaan lagi dan membuang dengan seenaknya sendiri. Kurang kesadaran akan pentingnya kebersihan menjadi faktor yang paling dominan, di samping itu kepekaan masyarakat terhadap lingkungan harus dipertanyakan. Mereka tidak mengetahui bahaya apa yang akan terjadi apabila tidak dapat menjaga lingkungan sekitar (Purbasari, 2014)

Sampah dari rumah tangga sebagaimana dalam PERDA Kota Medan No 6 tahun 2015 Sampah rumah tangga adalah sampah yang berasal dari kegiatan sehari-hari dalam rumah tangga yang tidak termasuk tinja dan sampah spesifik. Sampah yang di hasilkan dari kegiatan rumah tangga antara lain berupa sisa hasil pengolahan makanan,seperti sayursayuran, buah-buahan, barang bekas dan perlengkapan rumah tangga, kertas kardus, gelas, kain, tas bekas, sampah dari kebun, dan halaman, atau baterai dan lain-lain (Peraturan Daerah Kota Medan no 6tahun 2015).

Masalah sampah khususnya di Lingkungan IV Kelurahan Helvetia Kecamatan Medan Helvetia masih sangat membutuhkan perhatian khusus oleh pemerintahan kota Medan dengan adanya peranan dari ibu rumah tangga ini diharapkan timbunan sampah ditempat pembuangan akan dapat teratasi sehingga kesehatan dan kelestariaan lingkungan disekitar tempat tinggal akan terjaga. Sebagian besar masyarakat di Lingkungan IV Kelurahan Helvetia Kecamatan Medan Helvetia ini mempunyai kebiasaan buruk yaitu membuang sampah di pinggir jalan baik kanan maupun kiri dan bahkan sampai mengenai ke badan jalan yang sangat mengganggu aktifitas masyarakat yang melintasinya. dan sebagian besar yang banyak menyumbang sampah tersebut merupakan hasil dari sampah rumah tangga yaitu aktifitas atau kegiatan ibu rumah tangga untuk terjadinya tumpukan-tumpukan sampah yang ada di lingkungan IV tersebut (Kamal, 2017).

Berdasarkan uraian diatas maka peneliti tertarik untuk melaksanakan peneliti dengan judul "Faktor-Faktor Yang Berhubungan Dengan Membuang Sampah di Lingkungan IV Kelurahan Helvetia Kecamatan Medan Helvetia Tahun 2017'. 
BAHAN DAN METODE

Penelitian ini menggunakan jenis penelitian observasional analitik dengan menggunakan rancangan Cross Sectiona Rancangan

Lokasi penelitian ini dilakukan di Lingkungan IV Kelurahan Helvetia Kecamatan Medan Helvetia. Penelitian ini dimulai dengan penelusuran lingkungan masyarakat, melakukan survei awal, konsultasi judul dengan pembimbing, penyusunan proposal, seminar proposal, pengumpulan data penelitian, pengolahan data, penyusunan hasil penelitian, serta seminar hasil penelitian. Keseluruhan proses penelitian dilakukan dari bulan Febuari sampai dengan bulan Agustus 2017.

Populasi dalam penelitian ini adalah seluruh Ibu Rumah Tangga di Lingkungan IV Kelurahan Helvetia Kecamatan Medan Helvetia sebanyak 178 Ibu Rumah Tangga. Jumlah sampel yang digunakan sebanyak 123 orang ibu rumah tangga di Lingkungan IV Kelurahan Helvetia Kecamatan Medan Helvetia dengan menggunakan teknik Random Sampling atau secara acak sederhana

Data yang diambil dalam penelitian ini adalah data primer yaitu, data yang secara langsung diperoleh dari responden melalui wawancara dengan menggunakan kuesioner, yang diolah melalui tahapan editing, coding dan tabulating data.

Analisis data mengguakan analisa univariat, analisa bivariat melalui uji chi-square dan analisa multivariat melalui regresi linear logistik.

HASIL

Analisis Univariat

1. Karakteristik Responden

Tabel 1. Distribusi Frekuensi Karakteristik Responden

\begin{tabular}{lcc}
\hline \multicolumn{1}{c}{ Karakteristik } & f & \% \\
\hline Umur & & \\
\hline$>35$ Tahun & 40 & 32.5
\end{tabular}

\begin{tabular}{lcc}
$\leq 35$ Tahun & 83 & 67.5 \\
\hline Pendidikan & & \\
\hline Tinggi (D3/S1) & 18 & 14.6 \\
Menengah & 62 & 50.4 \\
(SMA/SMK) & 43 & 35.0 \\
Rendah (SD/SMP) & $\mathbf{1 2 3}$ & $\mathbf{1 0 0 . 0}$ \\
\hline \multicolumn{1}{c}{ Total } & $\mathbf{1 2 3}$
\end{tabular}

Tabel 1. menunjukkan bahwa pada umur responden mayoritas $\leq 35$ Tahun sebanyak 83 orang $(67,5 \%)$, dan pendidikan responden mayoritas menengah (SMA/SMK) sebanyak 62 orang $(50,4 \%)$.

\section{Variabel Penelitian}

Tabel 2. Distribusi Frekuensi Variabel Penelitian

\begin{tabular}{|c|c|c|}
\hline Varibel Penelitian & $\mathbf{f}$ & $\%$ \\
\hline \multicolumn{3}{|c|}{ Tindakan Membuang Sampah } \\
\hline Tidak baik & 79 & 64.2 \\
\hline Baik & 44 & 35.8 \\
\hline \multicolumn{3}{|l|}{ Pengetahuan } \\
\hline Tidak baik & 81 & 65,9 \\
\hline Baik & 42 & 34,1 \\
\hline \multicolumn{3}{|l|}{ Sikap } \\
\hline Negatif & 73 & 59.3 \\
\hline Positif & 50 & 40.7 \\
\hline \multicolumn{3}{|l|}{ Ketersediaan Sarana } \\
\hline Tidak Tersedia & 69 & 56.1 \\
\hline Tersedia & 54 & 43.9 \\
\hline \multicolumn{3}{|c|}{ Sosialisasi Petugas Kesehatan } \\
\hline Tidak Baik & 71 & 57.7 \\
\hline Baik & 52 & 42.3 \\
\hline \multicolumn{3}{|c|}{ Pengetahuan Tentang PERDA No 6} \\
\hline \multicolumn{3}{|l|}{ Tahun 2015} \\
\hline Tidak Baik & 75 & 61.0 \\
\hline Baik & 48 & 39.0 \\
\hline Total & 123 & $\mathbf{1 0 0 . 0}$ \\
\hline
\end{tabular}

Tabel 2. menunjukan bahwa tindakan mayoritas responden dalam membuang sampah dengan tidak baik sebanyak 79 orang $(64,2 \%)$. Pengetahuan responden mayoritas tidak baik sebanyak 81 orang $(65,9 \%)$. Mayoritas sikap responden dengan sikap negatif sebanyak 73 orang $(59.3 \%)$. Ketersediaan sarana mayoritas tidak tersedia sebanyak 69 orang (56.1\%). Sosialisasi petugas kesehatan dengan mayoritas tidak baik sebanyak 71 orang (57.7\%).Pengetahuan Tentang PERDA No 6 Tahun 2015 dengan mayoritas tidak baik sebanyak 75 orang $(61.0 \%)$. 


\section{Analisis Bivariat}

Tabel 3. Tabulasi Silang Faktor-Faktor yang Berhubungan Dengan Tindakan Membuang Sampah Di Lingkungan IV Kelurahan Helvetia Kecamatan Medan Helvetia Tahun 2017

\begin{tabular}{|c|c|c|c|c|c|c|c|}
\hline \multirow{3}{*}{$\begin{array}{c}\text { Faktor-Faktor yang } \\
\text { Berhubungan }\end{array}$} & \multicolumn{4}{|c|}{ Tindakan Membuang Sampah } & \multirow{2}{*}{\multicolumn{2}{|c|}{ Total }} & \multirow{3}{*}{ p value } \\
\hline & \multicolumn{2}{|c|}{ Tidak baik } & \multicolumn{2}{|c|}{ Baik } & & & \\
\hline & $\mathbf{n}$ & $\%$ & $\mathbf{n}$ & $\%$ & $\mathbf{n}$ & $\%$ & \\
\hline \multicolumn{8}{|l|}{ Sikap } \\
\hline Negatif & 55 & 75,3 & 18 & 24,7 & 73 & 100 & \multirow{2}{*}{$<0,004$} \\
\hline Positif & 24 & 48,0 & 26 & 52,0 & 50 & 100 & \\
\hline Jumlah & 79 & 64,2 & 44 & 35,8 & 123 & 100 & \\
\hline \multicolumn{8}{|l|}{ Pengetahuan } \\
\hline Tidak Baik & 67 & 82,7 & 14 & 17,3 & 81 & 100 & \multirow{2}{*}{$<0,001$} \\
\hline Baik & 12 & 28,6 & 30 & 71,4 & 42 & 100 & \\
\hline Jumlah & 79 & 64,2 & 44 & 35,8 & 123 & 100 & \\
\hline \multicolumn{8}{|l|}{ Pendidikan } \\
\hline Rendah & 40 & 93,0 & 3 & 7,0 & 43 & 100 & \multirow{3}{*}{$<0,001$} \\
\hline Menengah & 35 & 56,5 & 27 & 43,5 & 62 & 100 & \\
\hline Tinggi & 4 & 22,2 & 14 & 77,8 & 18 & 100 & \\
\hline Jumlah & 79 & 64,2 & 44 & 35,8 & 123 & 100 & \\
\hline \multicolumn{8}{|l|}{ Ketersediaan Sarana } \\
\hline Tidak Tersedia & 59 & 85,5 & 10 & 14,5 & 69 & 100 & \multirow{2}{*}{$<0,001$} \\
\hline Tersedia & 20 & 37,0 & 34 & 63,0 & 54 & 100 & \\
\hline Jumlah & 79 & 64,2 & 44 & 35,8 & 123 & 100 & \\
\hline \multicolumn{8}{|c|}{ Sosialisasi Petugas Kesehatan } \\
\hline Tidak Baik & 56 & 78,9 & 15 & 21,1 & 71 & 100 & \multirow{2}{*}{$<0,001$} \\
\hline Baik & 23 & 44,2 & 29 & 55,8 & 52 & 100 & \\
\hline Jumlah & 79 & 64,2 & 44 & 35,8 & 123 & 100 & \\
\hline \multicolumn{8}{|c|}{ Pengetahuan Tentang PERDA No 6 Tahun 2015} \\
\hline Tidak Baik & 54 & 72,0 & 21 & 28,0 & 75 & 100 & \multirow{2}{*}{$<0,040$} \\
\hline Baik & 25 & 52,1 & 23 & 47,9 & 48 & 100 & \\
\hline Jumlah & 79 & 64,2 & 44 & 35,8 & 123 & 100 & \\
\hline
\end{tabular}

Pada variabel sikap, dari 73 responden yang bersikap negatif mayoritas melakukan tindakan membuang sampah tidak baik yaitu $75,3 \%$. Sedangkan dari 50 responden yang bersikap positif mayoritas melakukan tindakan membuang sampah yang baik yaitu 52,0\%. Dari hasil uji statistik diperoleh $p$ value $=0,004$ yang artinya bahwa ada hubungan antara sikap ibu rumah tangga dengan tindakan membuang sampah.

Pada variabel pengetahuan, dari 81 responden yang berpengetahuan tidak baik mayoritas melakuakn tindakan membuang sampah tidak baik yaitu $82,7 \%$. Sedangkan dari 42 responden yang berpengetahuan baik mayoritas melakuakn tindakan membuang sampah yang baik yaitu $71,4 \%$. Dari hasil uji statistik diperoleh $p$ value $=$ $<0,001$ yang artinya bahwa ada hubungan antara pengetahuan ibu rumah tangga dengan tindakan membuang sampah.
Pada variabel pendidikan, dari 43 responden yang berpendidikan rendah mayoritas melakukan tindakan membuang sampah tidak baik yaitu 93,0\%. Sedangkan dari 62 responden yang berpendidikan menengah mayoritas melakukan tindakan membuang sampah yang tidak baik $71,4 \%$. Sedangkan dari 18 responden yang berpendidikan rendah mayoritas melakukan tindakan membuang sampah yang baik yaitu 77,8\%. Dari hasil uji statistik diperoleh $p$ value $=<0,001$ yang artinya ada hubungan antara tingkat pendidikan ibu rumah tangga terhadap tindakan membuang sampah.

Pada variabel ketersediaan sarana, dari 69 responden yang sarananya tidak tersedia mayoritas melakukan tindakan membuang sampah tidak baik yaitu $85,5 \%$. Sedangkan dari 54 responden dengan ketersediaan sarana yang tersedia mayoritas melakukan tindakan membuang sampah 
dengan baik yaitu 63,0\%. Dari hasil uji statistik diperoleh $p$ value $=<0,001$ yang artinya ada hubungan antara ketersediaan sarana dengan tindakan membuang sampah.

Pada variabel sosialisasi petugas kesehatan, dari 71 responden dengan sosialisasi petugas kesehatan yang tidak baik mayoritas melakukan tindakan membuang sampah tidak baik yaitu 78,9\%. Sedangkan dari 52 responden dengan sosialisasi petugas kesehatan yang baik mayoritas melakuakn tindakan membuang sampah dengan baik yaitu 55,8\%. Dari hasil uji statistik diperoleh $p$ value $=<0,001$ yang artinya ada hubungan antara sosialisasi petugas kesehatan terhadap tindakan membuang sampah.

Tabel 3. menujukkan bahwa dari 75 responden dengan Pengetahuan Tentang PERDA No 6 Tahun 2015 yang tidak baik mayoritas melakukan tindakan membuang sampah tidak baik yaitu 72,0\%. Sedangkan dari 48 responden dengan Pengetahuan Tentang PERDA No 6 Tahun 2015 yang baik melakukan tindakan membuang sampah dengan baik yaitu 47,9\%. Dari hasil uji statistik diperoleh $p$ value $=<0,040$ yang artinya ada hubungan antara Pengetahuan Tentang PERDA No 6 Tahun 2015 terhadap tindakan membuang sampah.

\section{Analisis Multivariat}

Tabel4. Model RegresiLogistik Tahap KetigaTindakan Dalam Membuang Sampah di Lingkungan IV Kelurahan Helvetia Kecamatan Medan Helvetia Tahun 2017

\begin{tabular}{lrrrrr}
\hline Varia & & & & \multicolumn{2}{c}{$\mathbf{9 5 \%}$ C.I } \\
\cline { 5 - 6 } bel & B & Sig. & OR & $\begin{array}{c}\text { Low } \\
\text { er }\end{array}$ & $\begin{array}{c}\text { Uppe } \\
\boldsymbol{r}\end{array}$ \\
\hline Penget & 2,4 & 0,0 & 8,6 & 3,2 & 41,5 \\
a-huan & 56 & 00 & 54 & 65 & 92 \\
Pendidi & 0,2 & 0,0 & 1,9 & 1,2 & 6,66 \\
-kan & 18 & 00 & 44 & 32 & 9 \\
Keterse & 2,5 & 0,0 & 7,2 & 3,5 & 49,1 \\
-diaan & 85 & 00 & 62 & 75 & 89 \\
Sarana & & & & & \\
Penget & & & & & \\
a huan & & & & & \\
tentang & 2,2 & 0,0 & 6,2 & 2,2 & 38,2 \\
PERD & 24 & 40 & 43 & 36 & 06 \\
A No & & & & & \\
6 tahun & & & & & \\
2015 & & & & & \\
Consta & - & 0,0 & 0,0 & & \\
nta & 4,5 & 00 & 10 & & \\
& 66 & & & &
\end{tabular}

Tabel 4 menunjukkan bahwa variabel pengetahuan, pendidikan, ketersediaan sarana, dan pengetahuan tentang PERDA no 6 tahun 2015 nilai $p<0,05$. Dengan demikian bahwa variabel yang paling dominan berhubungan dengan tindakan membuang sampah setelah dilakukan uji regresi logistik pada analisis multivariat adalah variabel pengetahuan $(\mathrm{p}=0,001$; $\mathrm{OR}=8,654 \quad 95 \% \mathrm{CI} 3,265-41,592) \quad$ yang artinya bahwa pengetahuanyang baik berpeluang berisiko 8,6 kali lebih besar melakukan tindakan membuang sampah secara baik dibanding dengan mereka yang memiliki pengetahuan yang tidak baik.

\section{PEMBAHASAN}

Hubungan Antara Tingkat Pengetahuan Dengan Tindakan Membuang Sampah

Hasil penelitian menunjukkan nilai $\mathrm{p}=$ $<0,001$ artinya bahwa ada hubungan pengetahuan dengan tindakan membuang sampah. Hal ini di dukung oleh penelitian (Azwar, 1996)Seseorang yang mempunyai pengetahuan baik tentang pengelolaan sampah disini diartikan sebagi pengetahuan yang terdiri dari pengertian sampah, jenis sampah, sumber sampah, faktor yang mempengaruhi produksi sampah, pengaruh sampah terhadap kesehatan, masyarakat dan lingkungan, syarat tempat sampah, kegiatan operasional pengelolaan sampah dan alat yang digunakan dalam pengelolaan sampah dan cara membuang sampah, maka mereka akan mempunyai perilaku yang baik pula. Menurut (Notoatmodjo, 2012) pengetahuan adalah hasil dari tahu, dan ini terjadi setelah orang melakukan pengindraan terhadap suatu objek tertentu. Pengindraan terjadi melalui pencaindra menusia, yakni indra penglihatan, pendengaran, penciuman, rasa dan raba. Sebagian besar pengetahuan manusia diperoleh malalui mata dan telingga. Pengetahuan umumnya datang dari pengalaman dan juga dapat diperoleh dari informasi yang disampaikan orang lain di dapat dari buku, surat kabar, atau media massa dan elektronik,Penelitian Rogers (1974), dalam Notoatmodjo (2013) mengungkap-kan bahwa sebelum orang mengadopsi perilaku baru didalam diri 
orang tersebut terjadi proses yang berurutan yaitu : Awareness, Interest, Trial dan Adoption. Demikian juga pendapat (Ginandra2015), yang mengajukan bahwa pengetahuan merupakan resultan akibat proses pengindraan terhadap suatu obyek,pengindraan tersebut sebagian besar berasal dari penglihatan dan pendengaran.Fungsi pengetahuan sebagai wujud perilaku pembuangan sampah dalam masyarakat bisa dinilai dari lingkungan yang lebih sederhana yaitu keluarga, terutama ibu rumah tangga yang banyak menyumbang untuk terjadinya penumpukan sampah. Menurut (Notoatmodjo, 2010) pengukuran atau penilaian, pengetahuan pada umumnya dilakukan melalui tes atau wawancara dengan alat bantu kuesioner berisi materi yang diukur dari responden. Dengan demikian diasumsikan bahwa pengetahuan seseorang dapat menggambarkan besarnya pengaruh sikap dan perilaku dalam perkembangan pribadi secara utuh dan mengerjakan aktivitasnya sehari-hari seperti halnya dalam pembuangan sampah sembarangan

Hasil penelitian menunjukkan bahwa dari 81 ibu rumah tangga yang berpengetahuan tidak baik terdapat 67 orang $(82,7 \%)$ yang membuang sampah secara tidak baik dan 14 orang $(17,3 \%)$ yang membuang sampah secara baik.. Sedangkan dari 42 ibu rumah tangga dengan pengetahuan tidak baik terdapat 12 orang $(28,6 \%)$ yang membuang sampah secara baik dan 30 orang $(71,4 \%)$ yang membuang sampah secara baik. Dari hasil Regresi Logistik juga menunjukkan bahwa variabel pengetahuan, pendidikan, ketersediaan sarana, dan Pengetahuan Tentang PERDA No 6 Tahun 2015 nilai $\mathrm{p}<0,05$. Dengan demikian bahwa variabel yang paling dominan berhubungan dengan tindakan membuang sampah setelah dilakukan uji regresi logistik pada analisis multivariat adalah variabel pengetahuan ( $p=0,001$; or=8,654 95\%ci 3,265-41,592) yang artinya bahwa pengetahuan yang baik berpeluang berisiko 8,6 kali lebih besarmelakukan tindakan membuang sampah secara baik dibanding dengan mereka yang memiliki pengetahuan yang tidak baik.
Hal ini berarti bahwa dengan pengetahuan respopnden yang kurang maka dapat mempengaruhi mereka membuang sampah secara tidak baik. Bila dilihat dari hasil penelitian ini sebagian responden sudah melakukan pembuangan sampah dengan baik, hal ini terjadi karena sebagian dari mereka mendapatkan informasi dari teman, tenaga kesehatan maupun tokoh masyarakat tentang membuang sampah, sedangkan yang lainnya banyak diantara mereka yang tidak mengetahui informasi Membuang sampah karena mereka jarang berkunjung ke tempat pelayanan kesehatan, jarang berkonsultasi dengan tenaga kesehatan serta kurangnya mencari informasi terkait kesehatan lingkungan, sehingga pemahaman mereka tentang Membuang sampah masing kurang. Hal inilah yang membuat mereka melakukan pembangan sampah secara tidak baik. Responden tidak memahami secara lebih mendetail tentang Membuang sampah tersebut. Dengan pemahaman yang rendah tersebut maka responden tidak bisa mengambil keputusan untuk melakukan pembuangan sampah dengan baik, apalagi jika tanpa dukungan dari orang-orang terekatnya (suami).Belum terbiasanya masyarakat setempat dalam Membuang Sampah secara baik, hal ini bisa terjadi akibat kurangnya pengetahuan dan pemahaman masyarakat tentang perilaku membuag sampah, Pengetahuan yang rendah tentang Membuang sampah secara nyata telah membuat lingkungan menjadi sangat tidak nyaman, dan hal ini perlu mendapat perhatian dan menjadi petunjuk awal bagi petugas terkait untuk membuat perencanaan dan monitoring program perilaku dalam membuang sampah.

\section{Hubungan Antara Sikap Dengan Tindakan Membuang Sampah}

Hasil penelitian menunjukkan nilai $\mathrm{p}$ $=<0,004$ artinya bahwa ada hubungan pengetahuan dengan tindakan membuang sampah. Hal ini di dukung oleh penelitian (Azwar, 1996) yang mengatakan bahwa terdapat hubungan antara sikap dengan tindakan membuang sampah rumah tangga, disamping itu sikap negatif responden dipengaruhi oleh beberapa 
faktor: yaitu rendahnya tingkat pendidikan dan pengetahuan yang kurang sehingga mendorong seseorang untuk bersikap negatif terhadap apa yang belum pernah mereka ketahui.

Menurut Saptono(2008), adanya sikap akan menyebabkan manusia bertindak secara khas terhadap objek-objeknya. Dengan kata lain sikap merupakan produk dari proses sosialisasi, seseorang memberikan reaksi sesuai dengan rangsangan yang ditemuinya. Sikap dapat diartikan suatu kontrak untuk memungkinkan terlihatnya suatu aktifitas Adanya niat untuk melakukan suatu kegiatan akhirnya sangat menentukan apakah kegiatan tersebut betul-betul dilakukan, seperti dalam hal pembuangan sampah sembarangan, sikap masyarakat dalam pembuangan sampah merupakan pembentuk utama dalam perilaku masyarakat, dimana masyarakat menerima informasi pembuangan sampah secara positif dengan cara menerima saran-saran yang diberikan oleh petugas atau tokoh masyarakat setempat meskipun belum pada tindakan yang nyata.

Hasil penelitian menunjukkan bahwa dari 73 orang yang memiliki sikap negatif terdapat 55 orang $(75,3 \%)$ yang melakukan tindakan membuang sampah secara tidak baik dan 18 orang $(24,7 \%)$ yang melakukan tindakan membuang sampah secara baik. Sedangkan dari 50 orang yang memiliki sikap positif terdapat 24 orang $(48,0 \%)$ yang melakukan tindakan membuang sampah secara tidak baik dan 26 orang $(52,0 \%)$ yang melakukan tindakan membuang sampah secara baik.

\section{Hubungan Antara Tingkat Pendidikan dengan tindakan Membuang Sampah}

Hasil penelitian menunjukkan nilai $\mathrm{p}$ $=0,001$ artinya bahwa ada hubungan tingkat pendidikan dengan tindakan membuang sampah. Hal ini sejalan dengan penelitian (Rahman, 2009) yang mengatakan membuang sampah rumah tangga dapat dinyatakan berhubungan antara tingkat pendidikan dengan membuang sampah rumah tangga dan tingkat keeratan hubungan antara tingkat pendidikan responden dengan membuang sampah rumah tangga dalam kategori sedang, dengan hasil penelitian dari 67 responden terdapat 39 orang responden memiliki pendidikan rendah dengan sebanyak 33 orang memiliki perilaku yang buruk dalam membuang sampah rumah tangga.

Hasil penelitian menunjukkan bahwa dari 43 orang yag memiliki pendidikan rendah terdapat 40 orang $(93,0 \%)$ yang Membuang Sampah secara tidak baik dan 3 orang $(7,0 \%)$ yang melakukan tindakan membuang sampah secara baik. Dan dari 62 orang yang memiliki pendidikan menengah terdapat 35 orang $(56 \%)$ yang melakukan tindakan membuang sampah secara tidak baik dan 27 orang (43\%) yang melakukan tindakan membuang sampah secara baik. Sedangkan dari 18 yang memiliki pendidikan tinggi terdapat 4 orang $(22,2 \%)$ yang melakukan tindakan membuang sampah secara baik dan 14 orang $(77,8)$ yang melakukan tindakan membuang sampah secara tidak baik. Hal ini berarti bahwa dengan tingkat pendidikan rendah maka dapat mempengaruhi tindakan membuang sampah secara tidak baik. Hal ini terlihat dari hasil penelitian dimana mayoritas yang memiliki pendidikan rendah cenderumg lebih banyak melakukan tindakan membuang sampah secara tidak baik.

Semakin tinggi pendidikan seseorang maka semakin mudah memberi informasi dan pembinaan selayaknya semakin tinggi kesadaran dan kemampuan masyarakat dalam berperilaku (Putra, 2013).

\section{Hubungan Antara Ketersediaan SaranaDengan Tindakan Membuang Sampah}

Hasil penelitian menunjukkan nilai $\mathrm{p}=0,001$ artinya bahwa ada hubungan ketersediaan sarana dengan tindakan membuang sampah. Hal ini sejalan dengan penelitian (Rahman, 2009) yang mengatakan bahwa ada hubungan antara ketersediaan sarana dengan perilaku masyarakat dalam membuang sampah rumah tangga, dengan tingkat keeratan hubungan dalam kategori sedang. Responden dengan sarana pembuangan sampah rumah tangga tidak ada dan berperilaku buruk dalam membuang sampah rumah tangga dalam 
hal ini adalah ketesediaan sarana tempat sampah.

Hasil penelitian menunjukkan bahwa dari 69 orang yang tidak memiliki ketersediaan sarana terdapat 59 orang $(85,5 \%)$ yang melakukan tindakan membuang sampah secara tidak baik dan 10 orang $(14,5 \%)$ yang melakukan tindakan membuang sampah secara baik. Sedangkan dari 54 orang yang memiliki ketersediaan sarana terdapat 20 orang $(37,0 \%)$ yang melakukan tindakan membuang sampah secara tidak baik dan 34 orang $(63,0 \%)$ yang melakukan tindakan membuang sampah secara baik. Hal ini berarti bahwa dengan tidak adanya ketersediaan sarana maka dapat mempengaruhi tindakan membuang sampah secara tidak baik. Hal ini terlihat dari hasil penelitian dimana mayoritas yang memiliki sikap negatif cenderumg lebih banyak melakukan tindakan membuang sampah secara tidak baik.

Kepala Dinas Kebersihan Medan, Endar Sutan Lubis, mengatakan bahwa pusat kota merupakan wilayah penyumbang sampah terbanyak, di Medan perharinya terdapat 2000 ton sampah diproduksi, sampah rumah tangga merupakan penyumbang terbanyak per hari ada 1500 ke 1600 ton, jadi diperkirakan per jiwa itu menghasikan satu kilogram sampah per harinya,sedangkan Kota Medan saat ini hanya memiliki satu TPA dengan luas lahan yang terbatas. oleh karena itu dituntut pengelolaan persampahan secara komprehensif dan terpadu dari hulu ke hilir, sekaligus budaya baru masyarakat Kota Medan untuk kualitas lingkungan hidup yang lebih baik.

Berdasarkan Undang-Undang No. 18 Tahun 2008 menyatakan bahwa, setiap orang berhak mendapatkan pelayanan dalam hal pengelolaan sampah secara baik dari pemerintah daerah atau pihak lain yang diberi tanggung jawab dalam pengelolaan sampah dan tempat pembuangan akhir. Setiap pemerintah daerah memiliki tugas melaksanakan pengelolaan sampah dan memfasilitasi penyediaan prasarana dan sarana pengelolaan sampah (UU No. 18 Tahun 2008).
Aminah (2016) mengatakan, diperlukan penyediaan fasilitas dan perlakuan yang benar agar TPS dapat digunakan untuk mengelola sampah dengan cara tertentu, sehingga tidak berdampak negatif terhadap lingkungan. Keberadaan TPS perlu mendapatkan perhatian yang serius dan evaluasi secara berkala agar dapat berfungsi secara baik.

Hasil tersebut dapat disimpulkan bahwa semakin lengkap fasilitas dan sarana yang tersedia maka akan semakin baik praktik dan perilakunya dalam hal membuang samah rumah tangga. Sarana yang paling banyak tidak dimiliki oleh responden adalah tempat sampah yang tidak dilengakapi dengan tutupnya. Hal ini karena beberapa hal diantaranya pembuatan tempat sampah dengan keadaan tertutup membutuhkan dana yang cukup besar, responden tidak memanfaatkan lahan yang ada, akan tetapi responden langsung membuang sampah rumah tangga begitu saja ke lahan kosong sehingga semangkin bertambahnya volume tumpukan sampah. Kurangnya tempat pembuangan sampah membuat orang sulit untuk membuang sampah dan jika tersedianya sarana maka akan semakin baik praktik dan perilakunya dalam hal membuang samah rumah tangga, Jadi, orang tidak akan membuang sampah sembarangan jika tersedianya banyak tempat sampah.

\section{Hubungan Antara Sosialisasi Petugas Kesehatan Dengan Tindakan Mem- buang Sampah}

Hasil penelitian menunjukkan nilai $\mathrm{p}$ $=0,001$ artinya bahwa ada hubungan sosialisasi petugas kesehatan dengan tindakan membuang sampah. Hal ini di dukung oleh penelitian (Saptono, 2008). Peran pemerintah, tokoh masyarakat dan masyarakat itu sendiri masih sangat diperlukan untuk mengajak dan menyadari arti pentingnya dalam pembuangan sampah di lingkungan keluarga, oleh sebab itu perlunya sosialisasi dari petugas kesehatan kepada setiap masyarakat dalam pembuangan sampah

Hasil penelitian menunjukkan bahwa dari 71 orang dengan sosialisasi petugas 
kesehatan yang tidak baik terdapat 56 orang $(78,9 \%)$ yang melakukan tindakan membuang sampah secara tidak baik dan 15 orang $(21,1 \%)$ yang melakukan tindakan membuang sampah secara baik. Sedangkan dari 52 orang dengan sosialisasi petugas kesehatan yang baik terdapat 23 orang $(44,2 \%)$ yang melakukan tindakan membuang sampah secara tidak baik dan 29 orang $(55,8 \%)$ melakukan tindakan membuang sampah sampah secara baik. Hal ini berarti bahwa dengan sosialisasi petugas kesehatan yang tidak baik dapat mempengaruhi tindakan membuang sampah secara tidak baik. Hal ini terlihat dari hasil penelitian dimana mayoritas sosialisasi petugas kesehatan yang tidak baik cenderumg lebih banyak melakukan tindakan membuang sampah secara tidak baik. Di dalam perda no 6 tahun 2015 juga mengatakan pengelolaan persam-pahan setiap orang berhak memperoleh pembinaan agar dapat melaksanakan pengelolaan persampahan secara baik dan berwawasan lingkungan.

Saptono (2008) mengatakan bahwa kurangnya sosialisasi pada keluarga juga mempengaruhi masalah dalam pembuangan sampah sembarangan. Masih banyak masyarakat yang membuang sampahnya secara sembarangan. kurangnya sosialisasi pemerintah (Dinas Kebersihan) kepada masyarakat akan dampak dari pembuang sampah sembarangan, bisa dibilang bahwa masih kurangnya penyuluhan atau sosialisasi terkait cara penanganan sampah, jika ada penyuluhan tentang sampah yang benar dan bagaimana cara efektifnya, mungkin lingkunagan sekitar akan terlihat indah dan bersih.

Dengan adanya sosialisasi, diharapkan masyarakat menegtahui pentingnya melakukan penanganan sampah sebelum melakukan ke pembuangan akhir, diharapkan lingkungan masyarakat dapat mempraktekkan cara pembuangan sampah dengan baik dan benar. Disamping itu, masyarakat diharapkan dapat memahami resiko dari membuang sampah sembarangan terhadap kehidupan manusia sehingga masyarakat dapat mengaplikasikannya dalam kehidupan sehari-hari. Artinya peran pemerintah, tokoh masyarakat dan masyarakat itu sendiri masih sangat diperlukan untuk mengajak dan menyadari arti pentingnya dalam pembuangan sampah di lingkungan keluarga. Oleh sebab itu perlunya sosialisasi dari petugas kesehatan kepada setiap ibu rumah tangga dalam pembuangan sampah.

\section{Hubungan Antara Pengetahuan Tentang PERDA No 6 Tahun 2015 Dengan Tindakan Membuang Sampah}

Hasil penelitian menunjukkan nilai $\mathrm{p}=0,040$ artinya bahwa ada hubungan Pengetahuan Tentang PERDA No 6 Tahun 2015 dengan tindakan membuang sampah.Hal ini di dukung oleh penelitian (Rosita Candrakirana, 2015) yang mengatakan bahwa sanksi-sanksi yang terdapat dalam peraturan terutama yang menyangkut dengan pembuangan sampah tidak memberikan efek jera bagi masyarakat yang tidak melakukan pembuangan sampah dengan berwawasan lingkungan sehingga perlu dikaji efektifitas penegakan hukum dalam pembuangan sampah. Selain itu peran pemerintah daerah juga sangat penting dalam mengeluarkan kebijakan terhadap pengelolaan sampah. Apabila daerah mampu mengelola sampahnya dengan baik maka pelaksanaan terhadap prinsip menata lingkungan sudah dapat dikatakan terpenuhi. Dapat disimpulkan bahwa pengambilan keputusan adalah suatu cara yang digunakan untuk memberikan suatu pendapat yang dapat menyelesaikan suatu masalah dengan cara atau teknik tertentu agar dapat lebih diterima oleh semua pihak. Pengambilan Kepurusan secara preventif berarti pengawasan aktif dilakukan terhadap kepatuhan kepada peraturan tanpa kejadian langsung yang menyangkut peristiwa konkrit yang menimbulkan sangkaan bahwa peraturan hukum telah dilanggar.

Hasil dari wawancara mendalam yang peneliti lakukan pada beberapa responden, selain kurangnya tempat pembuangan sampah mereka melakukan pembuangan sampah pada malam hari dan pada waktu subuh di tempat biasanya terjadi tumpukan sampah karna pada 
kondisi yang gelap tidak ada yang melakukan teguran kepada masyarakat sehingga masyarakat bisa melakukan pembuangan sampah secara tidak baik yang menyebabkan terjadinya tumpukantumpukan sampah tersebut, pada dasarnya mereka tidak mengetahui perda nomor 6 tahun 2015 apalagi sanksi yang diberikan ketika membuang sampah secara tidak baik.

Hasil penelitian menunjukkan bahwa dari 75 orang dengan Pengetahuan Tentang PERDA No 6 Tahun 2015 yang tidak baik terdapat 54 orang $(72,0 \%)$ yang melakukan tindakan membuang sampah secara tidak baik dan 21 orang $(28,0 \%)$ yang melakukan tindakan membuang sampah secara baik. Sedangkan dari 48 orang dengan Pengetahuan Tentang PERDA No 6 Tahun 2015 dengan baik terdapat 25 orang $(52,1 \%)$ yang melakukan tindakan membuang sampah secara tidak baik dan 23 orang (47,9\%) yang melakukan tindakan membuang sampah secara baik. Hal ini berarti bahwa dengan Pengetahuan Tentang PERDA No 6 Tahun 2015 yang tidak baik dapat mempengaruhi tindakan membuang sampah secara tidak baik. Hal ini terlihat dari hasil penelitian dimana mayoritas pengetahuan tentang PERDA No 6 tahun 2015 yang tidak baik cenderumg lebih banyak melakukan tindakan membuang sampah secara tidak baik.

Untuk mencegah terjadinya tindakan pelanggaran terhadap norma atau hukum, maka dibuatlah sanksi/denda dalam setiap norma atau hukum tersebut yaitu Peraturan Daerah Kota Medan Nomor 6 tahun 2015 tentang pengelolaan persampahan. dalam hukum pidana menganai sanksi yang diatur oleh PERDA Kota Medan nomor 6 tahun 2015 dalam pasal tersebut ditegaskan bahwa setiap orang yang melanggar ketentuan dipidana dengan pidana kurungan paling lama 3 bulan atau denda paling banyak 10.000.000 (sepuluh juta rupiah) (Peraturan Daerah Kota Medan Nomor 6, 2015).

Peristiwa ini sering kali kita saksikan dalam kehidupan sehari-hari. Misalnya, mengapa masyarakat berpilaku membuang sampah secara tidak baik, penyebabnya karena petugas tidak tegas menindaknya. Sanksi-sanksi yang terdapat dalam peraturan terutama yang menyangkut dengan pembuangan sampah tidak memberikan efek jera bagi masyarakat yang tidak melakukan pembuangan sampah dengan berwawasan lingkungan sehingga perlu dikaji efektifitas penegakan hukum dalam pembuangan sampah. Selain itu peran petugas kebersihan kotaberserta tokoh masyarakat juga sangat penting dalam memberikan tindakan terhadap pengelolaan sampah. Apabila daerah mampu mengelola sampahnya dengan baik maka pelaksanaan terhadap prinsip menata lingkungan sudah dapat dikatakan terpenuhi (Candrakirana, 2015).

\section{KESIMPULAN DAN SARAN Kesimpulan}

Berdasarkan hasil penelitian maka dapat diambil kesimpulan sebagai bahwa terdapat hubungan pengetahuan, sikap, tingkat pendidikan, ketersediaan sarana, sosialisasi petugas kesehatan, dan pengetahuan tentang PERDA No 6 tahun 2015dengan tindakan membuang sampah di lingkungan IV kelurahan helvetia kecamatan medan helvetia.Variabel yang paling dominan berhubungan dengan variabel tindakan membuang sampah adalah variabel pengetahuan bahwa pengetahuan yang baik berpeluang berisiko 8,6 kali lebih besar melakukan tindakan membuang sampah secara baik dibanding dengan mereka yang memiliki pengetahuan yang tidak baik.

\section{Saran}

1. Bagi Masyarakat

Diharapkan kepada Ibu Rumah Tangga dapat memahami resiko dari tindakan membuang sampah sembarangan terhadap kehidupan manusia sehingga masyarakat dapat mengapikasikanya dalam kehidupan sehari-hari.

2. Bagi Petugas Kesehatan

Diharapkan kepada pihak pemerintah setempat berkolaborasi dengan masyarakat dan petugas kesehatan agar memberikan sosialisasi melalui komunikasi langsung kepada ibu rumah tangga dengan melibatkan suami dan 
tokoh masyarakat, sehingga memudahkan ibu rumah tangga untuk memahami lebih dalam tentang pentingnya menjaga lingkunga serta menfasilitasi sarana seperti tempat sampah, memasang spanduk larangan membuang sampah, poster-poster larangan membuang sampah dan membagikan booklet Peraturan Daerah Kota Medan Nomor 06 Tahun 2015 tentang Pengelolahan Persampahan.

3. Bagi Peneliti Selanjutnya

Disarankan agar peneliti selanjutnya melakukan pengkajian tentang pemilahan sampah sehingga dapat di memanfaatkan dan meminimalisir untuk terjadinya timpukan sampah sampah yang berserakan.

\section{DAFTAR PUSTAKA}

Azwar, A., (1996). Pengantar Ilmu Kesehatan Lingkungan, Mutiara Sumber Penabur Benih, Jakarta

Aminah, C.S., (2016). Evaluasi Pengelolaan Tempat Pembuangan Akhir (Studi Kasus Tpa Ikhulung Kabupaten Aceh Barat Daya). Magister Ilmu Lingkungan Program Pasca sarjana Universitas Diponegoro Semarang.

Candrakirana, R., (2015). Penegakan Hukum Lingkungan Dalam Bidang Pengelolaan Sampah Sebagai Perwujudan Prinsip Good Environmental Governance Di Kota Surakarta. Fakultas Hukum Universitas Sebelas Maret Surakarta.

Kamal, F., (2009). Hubungan Antara Tingkat Pengetahuan Dan Sikap Ibu Rumah Tangga Tentang Pengelolaan Sampah Dengan Perilaku Pembuangan Sampah Pada Masya-rakat Sekitar Sungai Beringin Di Rw 07 Kelurahan Wonosari Kecamatan Ngaliyan Kota Semarang Tahun 2009. Jurusan Ilmu Kesehatan Masyarakat Fakultas Ilmu Keolah-ragaan.

Kamal. (2017). Kepala Lingkungan IV Kelurahan Helvetia Kecamatan Medan Helvetia. Wawancara interview. 16 Maret. 2017.

Notoatmodjo, S. (2007). Kesehatan Masyarakat Ilmu dan Seni. Rineka Cipta. Jakarta.
(2010). Ilmu Prilaku Kesehatan. Rineka Cipta. Jakarta.

Partneship, (2011). Mekanisme KPS Sektor Pengelolaan Sampah Bersahabat dengan Sampah.Menuju Zero Waste, and Waste to Energy.

Peraturan Daerah Kota Medan Nomor 6 Tahun 2015 (2015, oktober 12). Pemerintah kota medan dinas kebersihan. Pengelolaan persampahan.

Purbasari, N., (2014). Pemberdayaan Masyarakat Melalui Kegiatan Daur Ulang Sampah Plastik (Studi Kasus Ada Komunitas Bank Sampah Poklili Perumahan Griya Lembah Depok Kecamatan Sukmajaya Kota Depok). Jurusan Pendidikan Ilmu Pengetahuan Sosial. Fakultas Ilmu Tarbiyah Dan Keguruan Universitas Islam Negeri (Uin) Syarif Hidayatullah Jakarta 2014.

Putra, H.P., (2013). Studi Hubungan antara Tingkat Pendidikan dan Pendapatan Keluarga terhadap Sikap dalam Pengelolaan Sampah Rumah Tangga Teknik LingkunganFakultas Teknik Sipil dan Perencanaan, Universitas Islam Indonesia 2013.

Rahman, M., (2009). Analisis FaktorFaktor yang Berhubungan Dengan perilaku Masyarakat Dalam Membuang Sampah Rumah Tangga Di Sungai Mranggen. Jurusan Ilmu Kesehatan Masyarakat Fakultas Ilmu Keolahragaan Universitas Negeri Semarang 2009

Saptono, I, B. (2008). Faktor-faktor yang berhubungan dengan Partisipasi pria alam keluarga berencana Di kecamatan jetis kabupaten bantul Tahun 2008. Universitas Dipone-goro Semarang.

Slamet S. (2009). Kesehatan lingkungan, pustaka Universitas Sumatera Utara.

World Health Organization, (2007). Wastes From Health Care Activities. Diakses Pada Tanggal 14 Maret Dari. http://www.who.Int/mediacentre/ Factsheets/ Fs253/En/(diakses tanggal 27 maret 2017). 